\title{
Finite Element Simulation of the Instrumented Indentation Test to Estimate the Mechanical Properties for ASTM516-G70 and AISI1010 steels
}

\author{
Ahmed. F. Elmisteri, Abdelbaset R. H. Midawi, Farag M Shuaeib* \\ Mechanical Engineering Department, University of Benghazi, Benghazi, Libya
}

Received: 14 March 2019/ Accepted: 15 November 2019

Doi: https://doi.org/10.54172/mjsc.v34i3.273

Abstract: Instrumented indentation technique at micro-scales has become more popular to determine mechanical properties of materials like hardness, modulus of elasticity, and yield strength. It is introduced as a method that finds the stress-strain curve, instead of the traditional tensile test. Furthermore, it gives a possibility to determine the mechanical properties for small specimens and material under operation in the field. Several researchers have attempted to evaluate this method experimentally and to investigate the factors affecting it by using a different shape of indenters, and different types of materials. In the same regard, this research work is conducted to evaluate this method experimentally and by finite element simulation methods. Two types of industrially significant steels were selected; they are namely ASTM516-G70, AISI1010 steel; and two shapes of indenters, blunt and sharp (Spherical, and Vickers) were used. The finite element simulation has been performed by ABAQUS simulation program, and its results were then compared with the experimental test results obtained from Nanovea instrumented indentation test machine. The results obtained have demonstrated good agreement between the experimental and the finite element simulation results within $5 \%$ difference for young's module, and $7.7 \%$ for yield strength whereas excellent agreement is observed in the elastic region and the beginning of the plastic region for the engineering stress-strain curve. Finally, it is to be emphasized that the obtained results are more applicable for the tested materials, and further research is recommended to accommodate other materials as well and to confirm the generality of this method.

Keywords: finite element simulation; ABAQUS; Instrumented indentation.

\section{INTRODUCTION}

An instrumented indentation test or sometimes called depth-sensing indentation instrument is used to obtain mechanical properties such as hardness, Young's modulus, and yield strength by calculation from indenter load-displacement curve. This test can be performed on a microscopic scale and on the field measurement as it is considered as a non-destructive testing method. Fig. (1) shows a photo of the Nanovea Micro-Nano hardness test machine CB500 which is used in this work (Nanovea, 2019).

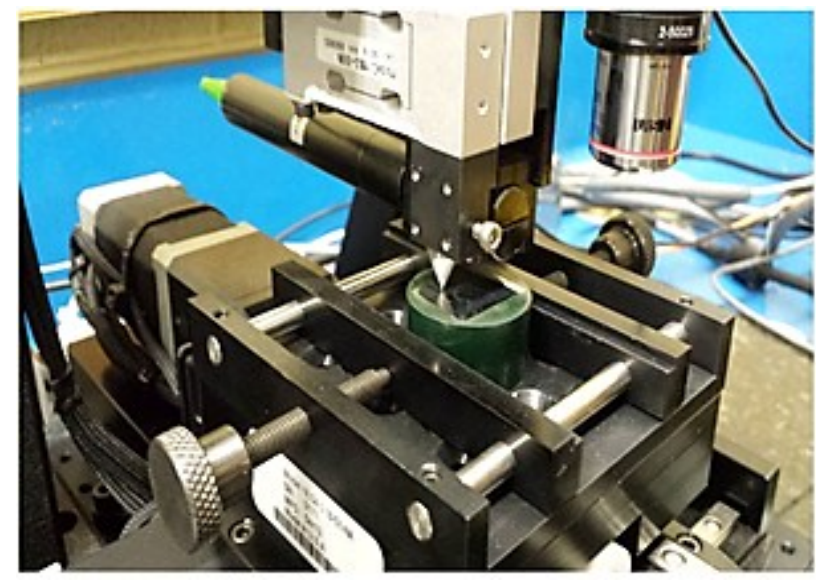

Figure (1). Nanovea Micro-Nano hardness test machine CB500.

*Corresponding Author: Farag M Shuaeib drfmshuaeib@gmail.com Mechanical engineering, university of Benghazi, Benghazi, Libya. 
This method is partially new and underdevelopment to be more flexible and trust-worthy in use. The elastic-plastic response of materials to micro indentation is not well understood in either an experimental or a theoretical context, nor is there enough experimental information available to support proposed models (Chiang, Marshall, \& Evans, 1982). Determination of the exact shape of the indenter at the tip is important to the measurement of both hardness and elastic modulus for indentation depths lees than a micro-scale (Doerner \& Nix, 1986). Finite element method has been used to simulate the conical indentation hardness test. Indentation Loaddepth curves were obtained, and the elastic modulus was calculated. Results justified and showed that the shapes of the plastic zones depend strongly on both the indenter angle and the ratio of young's modulus to yield strength. Where the yield zone of Aluminum $\left(E / \sigma_{y}=157.1\right)$ is bigger than the yield zone of silicon $\left(E / \sigma_{y}=28.8\right)$ (Bhargava \& Sharma, 1990). Because of the non-linear nature of the Nano-indentation hardness test to obtain the mechanical properties of implanted layers and thin films, the finite element numerical modeling has been attempted, and the commercial finite code ABAQUS was used. The yield strength, Young's modulus, and hardness of the layer material extracted, with an absolute accuracy of at least 20\%(Knapp, Follstaedt, Barbour, \& Myers, 1996). Improving test equipment for instrumented indentation method and consideration to the error sources, like error due to pile-up, is a way to make it more accurate. Test procedures and concepts are still demanding to improve the method that was introduced before 10 years (Oliver \& Pharr, 1992). Recently, good agreement between the experiment Nano indentation hardness test for bulk material and finite element simulation in two-dimensional (2-D) axisymmetric model and a three dimensional (3-D) model have been obtained by using finite element ABAQUS code (Panich, Kraivichien, \& Yong, 2004). Nu- merical simulations of pure copper, pure titanium, pure iron, and copper film were obtained using ABAQUS. It was found that the result depended greatly on mesh size, indenter radius, and the hardening law used (Bressan, Tramontin, \& Rosa, 2004). Also, a finite element model for a spherical indentation test for metallic substrates has been developed. The results were found to be relatively in close agreement to experimental data with a very minor effect of Poisson's ratio on the load-displacement curve but were less successful for polymeric materials because of the effects of anisotropy strain rate dependence e.g., viscosity (Clayton, 2005). Continuous instrumented indentation test with the Oliver-Pharr method using Vickers's indenter under load values from (10 to $100 \mathrm{~N})$ was performed to determine the mechanical properties of Carbide/aluminum composites. For Vickers hardness numbers, determined by the Oliver-Pharr method and by conventional hardness measurement, they are found to be in good agreement (Chen, 2009; Kimmari \& Kommel, 2006), concluded that the finite element method (FEM) is an effective tool for simulation of Nano-indentation test on metallic films, and the limitations caused by the simplification of models and assumptions should not be neglected (Chen, 2009).

(Midawi, Kisaka, Santos, \& Gerlich, 2016) found good agreement between yield strength obtained from instrumentation hardness test and yield strength obtained from a tensile test for weld zone of X80 pipeline steel (Midawi et al., 2016). Therefore, in this study, finite element method is adopted to build the indentation model with different indenters' geometries in order to understand the contact properties for each indenter shape and to evaluate the test using different materials. After model building, the target is to determine the FE load-displacement curves and compare it with the experimental curves to validate the FE models. Then after model validation, a sensitivity analysis would be performed by changing friction coefficient, boundary condition, 
and strain hardening exponent to find the effect of that on the load-displacement curve. Then the mechanical properties and the stress-strain curves would be generated and compared with experimental values.

\section{METHOD AND BASIC THEORY}

Nano-indentation hardness test, which is called Instrumented Indentation Hardness test or depth-sensing indentation test, is becoming a popular application of contact mechanics used to measure hardness and extract other mechanical properties such as elastic modulus and yield strength. This is achieved by measuring the indenter penetration " $\mathrm{h}$ " under the applied force $\mathrm{P}$ throughout the testing cycle and continue to record the change of the penetration depth after the load removed. The output is called load-displacement curve as shown in (Fig.2 and 3), where " $h_{\max }$ " represent the maximum indenter displacement at peak indentation load $P_{\text {max }}, "$ S $\mathrm{S}^{\prime \prime}$ is the initial unloading slope of the load-displacement curve, and " $h_{c}$ " is the contact depth. From this curve, an elastic solution can determine hardness, elasticity modulus, and other mechanical properties.

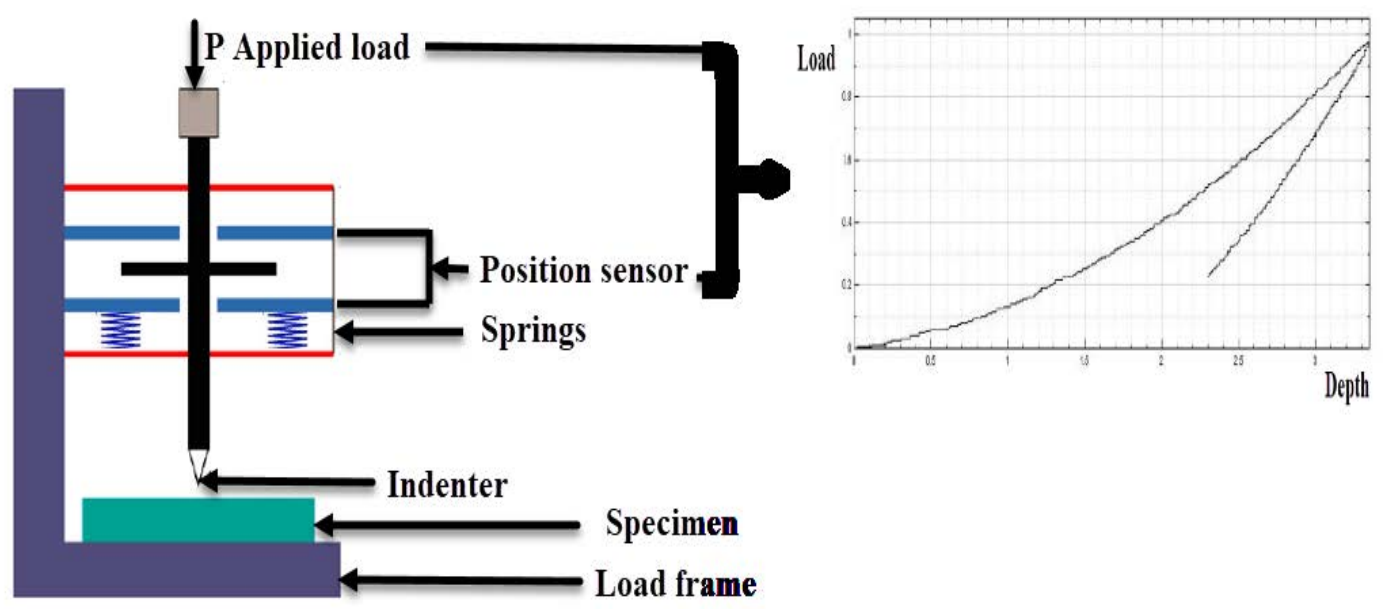

Figure (2). Schematic illustration of an instrumented indentation system.

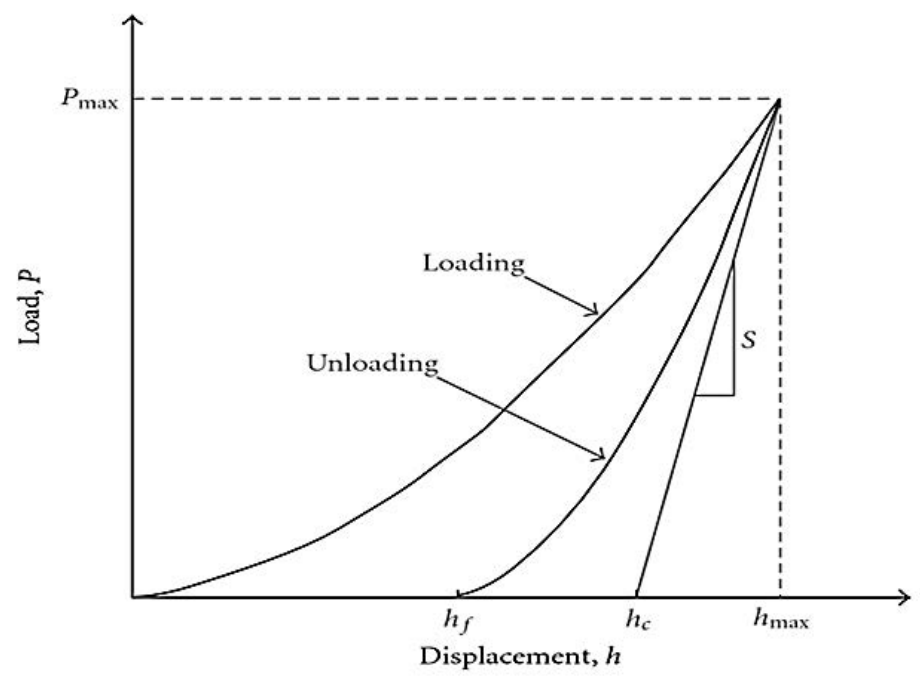

Figure (3). Load-Displacement curve for indentation test.

(C) 2019 The Author(s). This open access article is distributed under a CC BY-NC 4.0 license. 
The hardness can be found by dividing the maximum load by the area of contact or project area, which is determined by the depth of the impression and the known angle or radius of the indenter.

$$
H=\frac{P_{\max }}{A}
$$

The Oliver-Pharr method was originally developed to measure the hardness and elastic modulus of a single-phase elastic-plastic material from the indentation load-displacement curve with sharp indenters, such as Berkovich tip. It has been proven that this method can also be applied in any axisymmetric indenter geometries, including a sphere. As shown in equation (2), the Oliver-Pharr method begins by fitting the unloading portion of the indentation load-displacement data to the power-law relation.

$P=\alpha\left(h-h_{f}\right)^{m}$

Where

$\alpha, m$ are the fitting parameters

$h_{f}$ is the final depth after complete unloading.

The slope of the unloaded curve in equation (2) represents the stiffness, and by using it in equation (4) the Reduced modulus can be found as follows:

$S=\frac{d p}{d h}$

$\mathrm{S}=\frac{2}{\sqrt{\pi}} \mathrm{E}^{*} \sqrt{\mathrm{A}_{p}}$

Where $A_{p}$ is the project area.

For spherical indenter according to Multiplepoint unloading method, the project area equal to:

$\mathrm{A}_{p}=\pi * a^{2}$

$a=\sqrt{2 * R_{i} * h_{p}}$

Where:

$R_{i}$ is the indenter radius.

$h_{p}$ is the plastic penetration depth.

For Vickers indenter, the relationship between

the projected area $A_{p}$ of the indentation and the diagonal diameter $d$ is:

$A_{P}=\frac{d^{2}}{2 \cos 22}=\frac{d^{2}}{1.845368}$

Thus:

$\frac{d P}{d h}=\frac{d}{\gamma} E^{*} \sqrt{\frac{2}{\pi}}$

Where $\gamma$ is the correction factor equal to 1.0124 for Vickers indenters.

According to Hertz theory, the Reduced modulus or the combined modulus of the indenter and the specimen $E^{*}$ is given by equation (9) as follows (Fischer-Cripps \& Nicholson, 2002):

$\frac{1}{E^{*}}=\frac{\left(1-v^{2}\right)}{E}+\frac{\left(1-v^{2}\right)}{E}$

Where

$\grave{E} \dot{v}^{2}$ the elastic modulus and Poisson's ratio of the indenter

$E v^{2}$ the elastic modulus and Poisson's ratio of the specimen.

At this stage, determination of the modulus of elasticity for the specimen is possible as shown by equation (10).

$E=E^{*} *\left(1-v^{2}\right)$

Where $\frac{\left(1-v^{2}\right)}{\grave{E}}$ is too small because the indenter is totally rigid (means $\grave{E}$ has a big value ).

Extraction of the stress-strain curve from the load-displacement curve is by the configuration of the constraint factors, which connect between the normal stress-strain and indentation stress-strain as shown (Rabinowicz \& Tabor, 1951):

$\sigma_{\text {eff }}=\frac{\sigma_{\text {ind }}}{\psi}$

$\varepsilon_{\text {eff }}=\beta * \varepsilon_{\text {ind }}$

Where: $\psi$ is the stress constraint factor and $\beta$ is the strain constraint factor and their values depend on the material. Generally, the indentation strain constraint factor $\beta$ is considered to be equal to 0.2 , and the indentation stress constraint factor $\psi$ ranges from 2.8 to 3.2 (Yang \& (C) 2019 The Author(s). This open access article is distributed under a CC BY-NC 4.0 license. ISSN: online 2617-2186 print 2617-2178 
Li, 2008). The stress and strain constraint factor have empirical values according to Taber's theory and depended on material properties as shown in Table 1 (Xu \& Chen, 2010).

Table (1). Constraint factors for different materials $(\mathrm{Xu}$ \& Chen, 2010).

\begin{tabular}{llllll}
\hline \hline Materials & $\begin{array}{l}\mathrm{E} \\
(\mathrm{GPa})\end{array}$ & $\mathrm{n}$ & $E_{/} \sigma_{y}$ & $\psi$ & $\beta$ \\
\hline Iron & 211 & 0.26 & 2970.9 & 3.81 & 0.141 \\
Steel & 210 & 0.1 & 420 & 4.1 & 0.105 \\
Steel1 & 211 & 0.12 & 378.33 & 4.05 & 0.11 \\
SUS304 & 196 & 0.27 & 965.517 & 3.7 & 0.138 \\
Aluminum & 70 & 0.295 & 5622 & 3.71 & 0.131 \\
Al7039OA & 71 & 0.115 & 265.6 & 4.05 & 0.11 \\
Cu-51100 & 113.69 & 0.076 & 256.6 & 4.11 & 0.091 \\
Cu-10200 & 110.24 & 0.305 & 3991.31 & 3.52 & 0.158 \\
Cu-17510 & 124.02 & 0.11 & 204.26 & 4.01 & 0.101 \\
Cu20 & 110 & 0.485 & 25217 & 3.23 & 0.131 \\
Cu5.3 & 125 & 0.52 & 28115 & 3.06 & 0.152 \\
Au & 82 & 0.25 & 2050 & 3.82 & 0.139 \\
Inconel & 170 & 0.293 & 646.39 & 3.80 & 0.146 \\
A5051 & 73 & 0.126 & 948.05 & 4.01 & 0.122 \\
Brass & 96 & 0.36 & 1633.8 & 3.51 & 0.154 \\
\hline \hline
\end{tabular}

According to many researches (Chang, Garrido, Ruiz-Hervias, Zhang, \& Zhang, 2018; Karthik, Kasiviswanathan, \& Raj, 2016), the values of stress and strain constraint factors for steel are still under investigation and fluctuating between 0.11 to 0.2 for strain constraint factor and 2.87 to 4.1 for stress constraint factor.

As shown in equation (13) the indentation stress is equal to the indentation applied load divided by the contact or project area presented in equation (5).

$\sigma_{\text {ind }}=\frac{P}{A_{P}}$

According to Oliver -Pharr method, the radius of contact $a$ for spherical indenter is calculated from the following equation (14).

$a=\sqrt{2 * R_{i}\left(h-\frac{0.75 * P}{S}\right)-\left(h-\frac{0.75 * P}{S}\right)}$
Where $h$ is the penetration depth.

Also, Tabor defines the indentation strain as

$\varepsilon_{\text {ind }}=0.2 \frac{a}{R_{i}}$

\section{FINITE ELEMENT SIMULATION}

Materials and Experimental Test: As a reference material, AISI 1010 and ASTM 516 G70 were chosen. These materials were chosen as they are very popular in oil and gas industry and also in electrical power stations. The main equipment made from these materials includes pipelines and pressure vessels (see Fig.4). The mechanical properties for these materials are as shown in Table (2).

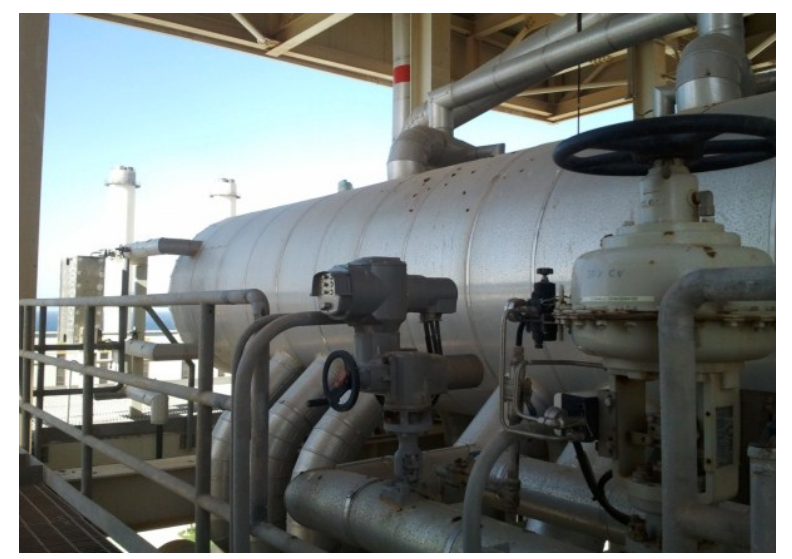

Figure (4). low-pressure heat-recovery steam generation tank in North Benghazi power station used high strength steel alloy ASTM A516-70.

The mechanical properties for these materials are as shown in Table (2). These values obtained experimentally from the tensile test.

Table (2). Mechanical properties of the considered materials.

\begin{tabular}{lccc}
\hline \hline Materials & $\begin{array}{c}\text { Young's } \\
\text { modulus } \\
\mathrm{E}(\mathrm{GPa})\end{array}$ & $\begin{array}{c}\text { Yield } \\
\text { strengt } \\
\mathrm{h} \sigma_{y}\end{array}$ & $\begin{array}{c}\text { Poisson's } \\
\text { ratio }\end{array}$ \\
\hline AISI1010 & 205 & 220 & 0.203 \\
ASTM516G70 & 240 & 260 & 0.23 \\
\hline \hline
\end{tabular}

The indentation test experiment was performed using the Nanovea mechanical testers, at a maximum load $10 \mathrm{~N}$ for spherical indentation 
and $4 \mathrm{~N}$ for Vickers indentation. The unloading curves were used to derive the modulus values by the analytical technique developed by Oliver and Pharr.

Modeling Procedure: In this model, the indentation test of bulk materials with isotropic elastic and plastic properties was simulated by the capability of the ABAQUS finite element (FE) code. (Fig.5) and (Fig.6) show the View of the Spherical and Vickers indentation models. Because of the symmetries of both geometry and loading conditions, the present indentation problem can be reduced to an axisymmetric (2dimensional) model. The specimen is modeled as an axisymmetric geometry with four-node axisymmetric quadrilateral continuum elements with reduced integration $(\mathrm{CAX} 4 \mathrm{R}$ in ABAQUS) (Abaqus, 2014). Since the indenter is much stiffer than the specimen, the indenter is considered to be perfectly rigid and is modeled as an analytical rigid surface. Because of the assumed total rigidity for the indenter, there is no need to mesh the indenter as no deformation happens during the test.
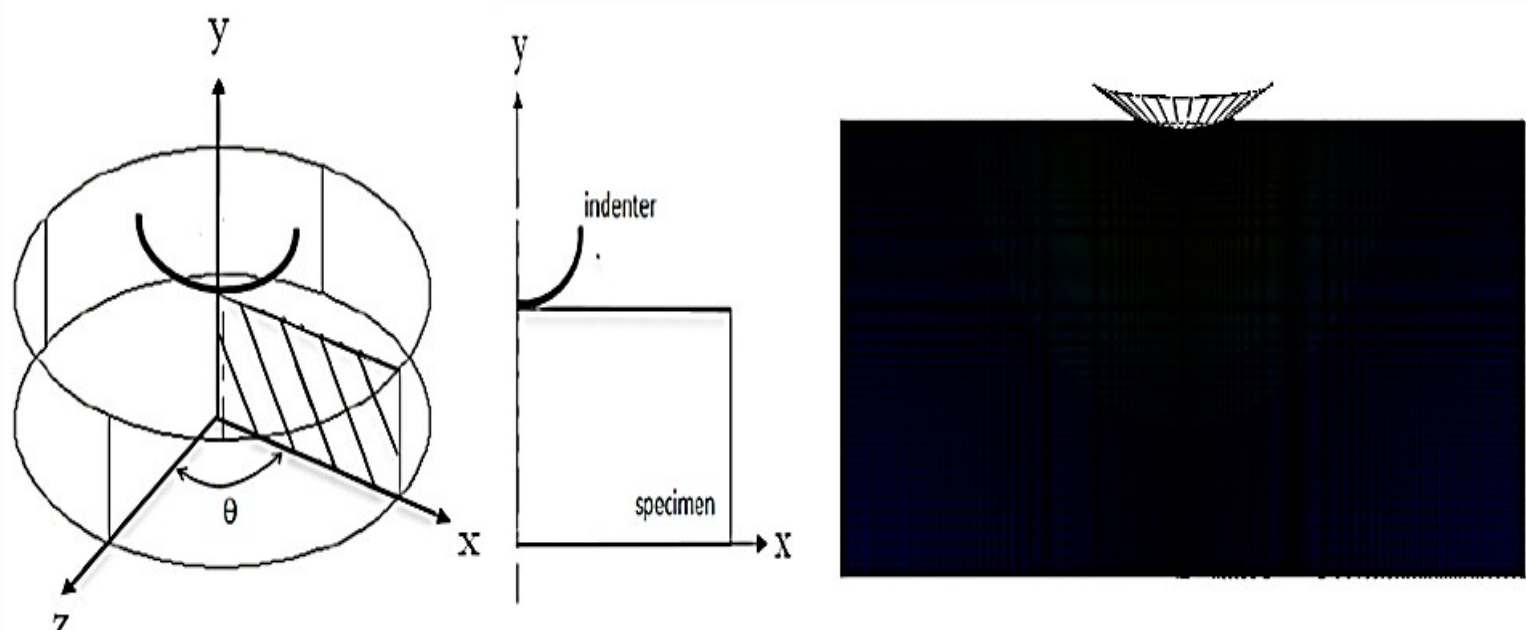

Figure (5). Diagrams show that a 3-D indentation problem can be solved using a 2-D axisymmetric model for Spherical indentation.
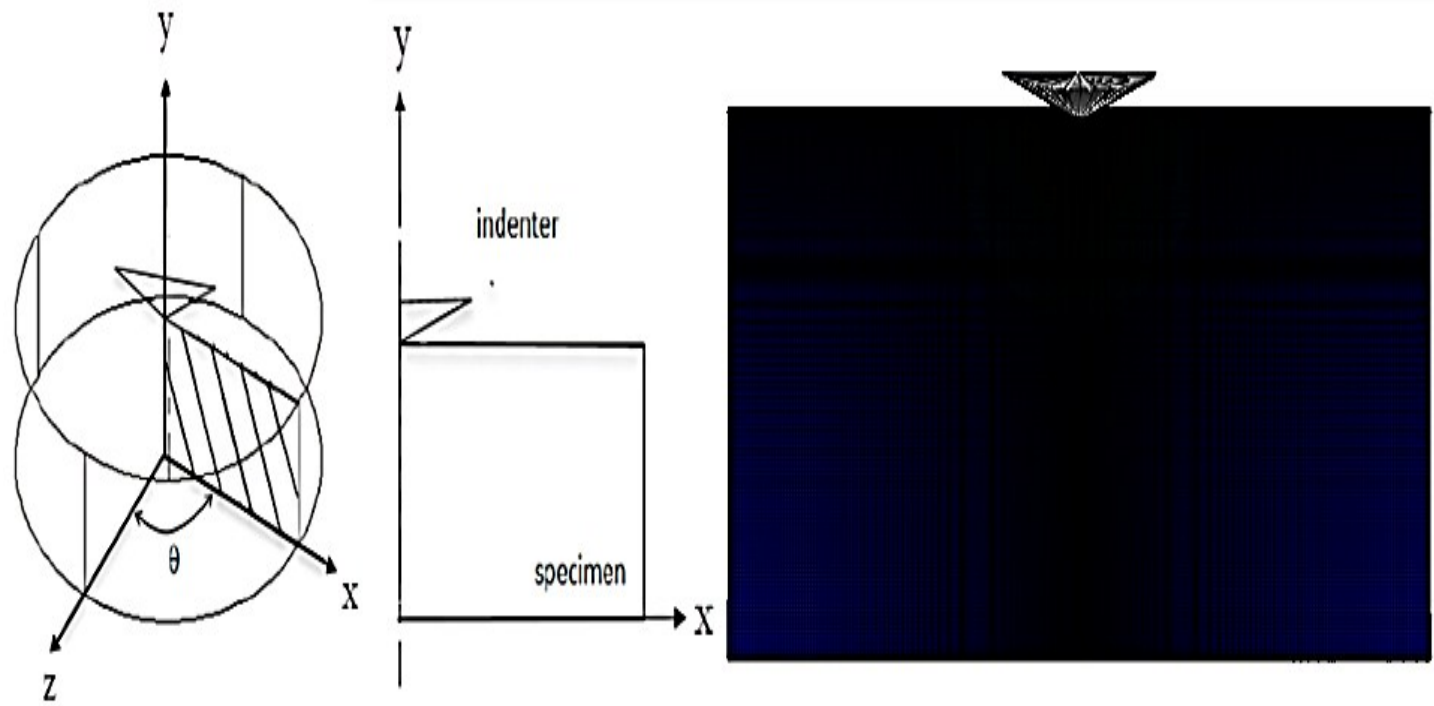

Figure (6). Diagrams show that a 3-D indentation problem can be solved using a 2-D axisymmetric model for Vickers indentation.

(C) 2019 The Author(s). This open access article is distributed under a CC BY-NC 4.0 license.

ISSN: online 2617-2186 print 2617-2178 
The specimens are modeled with 38416 fournode axisymmetric reduced integration elements (CAX4R element type) for spherical indentation and 43681 for Vickers indentation.
A fine mesh is used around the contact area and near the tip of the indenter. The mesh is continuously coarser further away from the tip, as shown in (Fig. 7) and (Fig. 8).

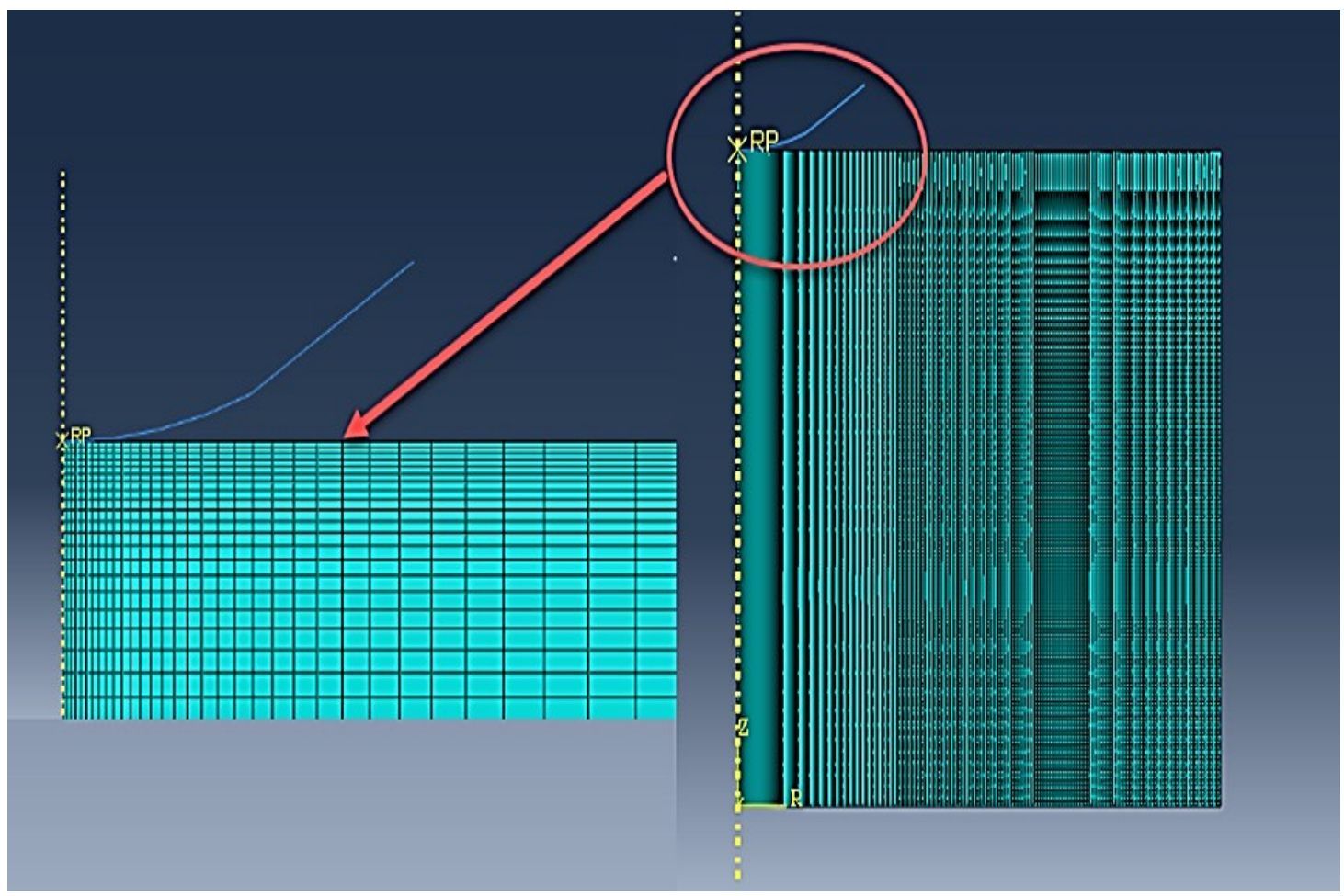

Figure (7). Meshing density illustration for spherical indentation (38416 elements)

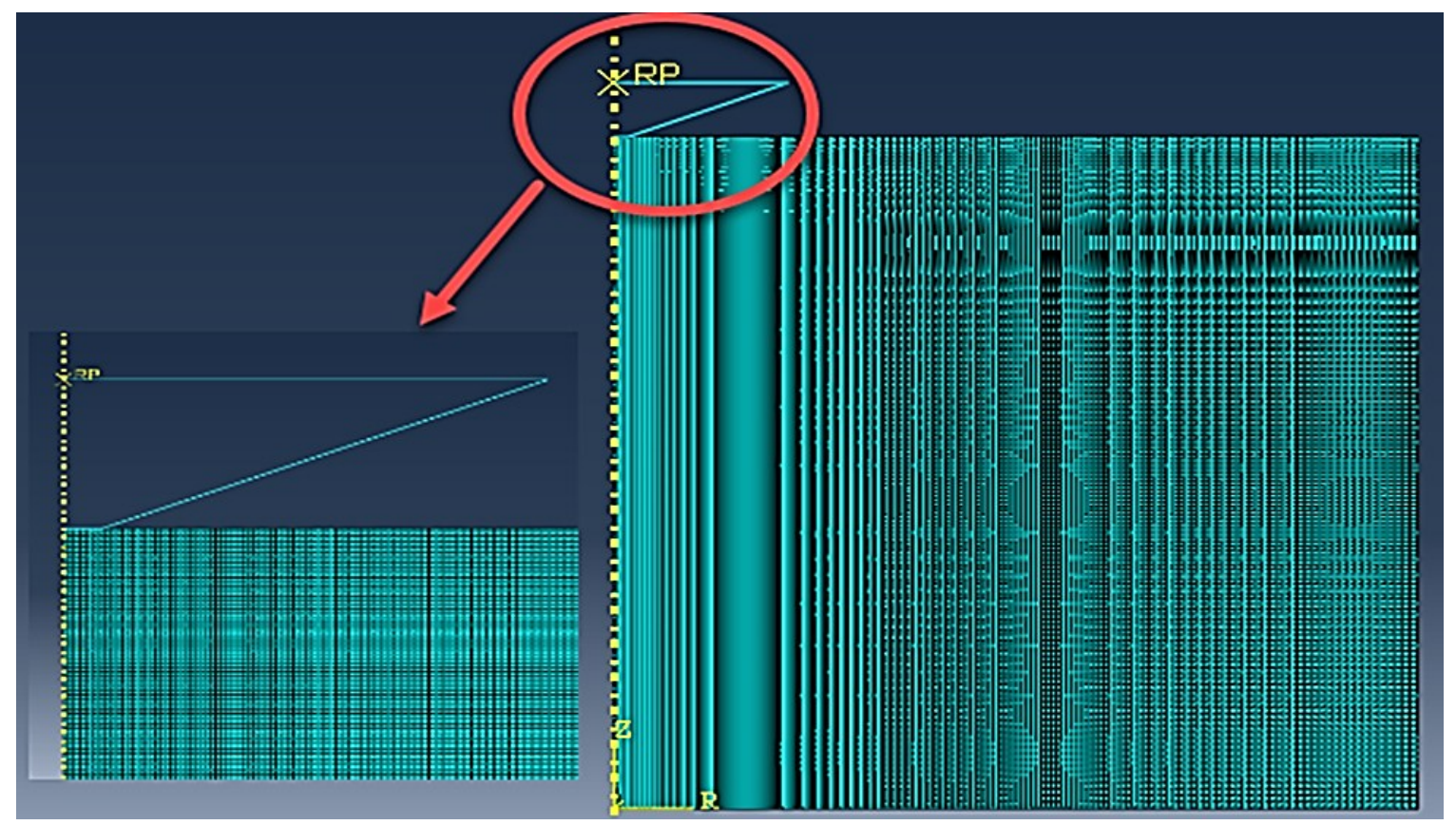

Figure (8). Meshing density illustration for Vickers indentation (43681 elements).

(C) 2019 The Author(s). This open access article is distributed under a CC BY-NC 4.0 license. ISSN: online 2617-2186 print 2617-2178 
The indentation process is simulated both during the loading and unloading steps. During the loading process, the simulation is performed to a depth of $10 \mu \mathrm{m}$ in the y-direction (U-2) into the specimen; and during the unloading process, the indenter tip returns to the initial position as shown in (Fig.9) and (Fig.10).

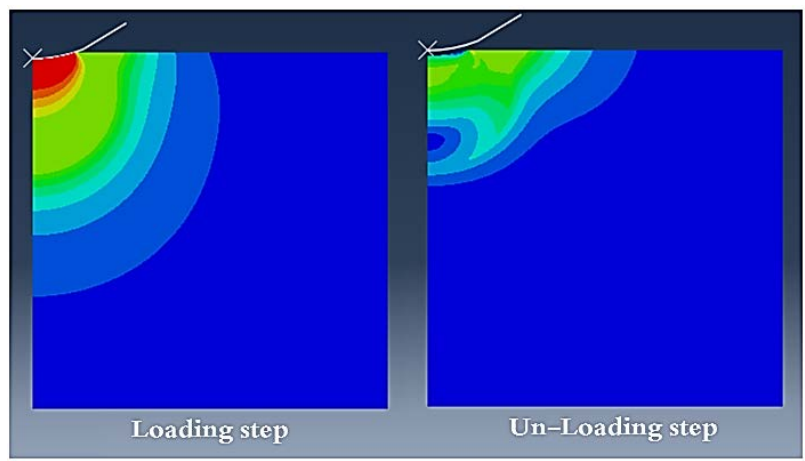

Figure (9). Loading and Unloading steps for spherical indentation (Colors represent Stress, Von-Mises)

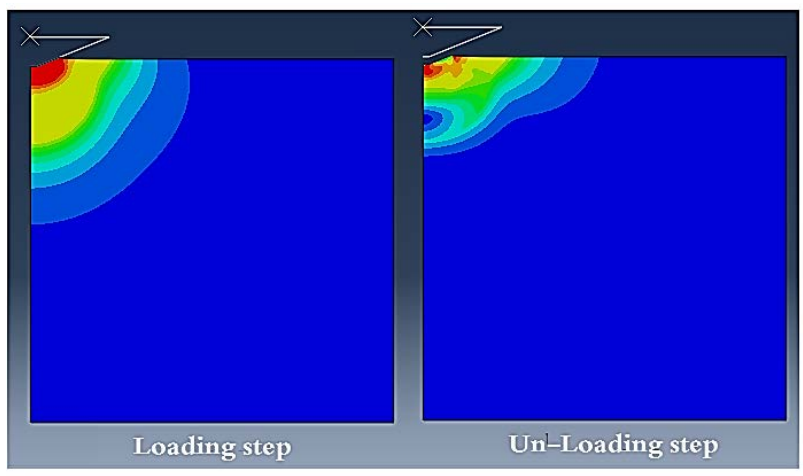

Figure (10). Loading and Unloading step for Vickers indentation (Colors represent Stress, Von-Mises)

The contact constraint is defined by the master and the slave surfaces. Because only the master surface can penetrate into the slave surface, the contact direction is then determined by the master surface. The model chooses the indenter as the master surface and the specimen as the slave surface. The boundary conditions are applied along with the original point, centerline, and bottom of the specimen.

The Micro indentation model developed was based on the following assumptions:

- There is a perfect interface between the indenter and the substrate so that the indenter and the substrate will not be separated during the indentation process.
- The friction between the indenter tip and the specimen surface is assumed to be zero.

- In the calculation, the elastic deformation occurs at the beginning of the process. The specimen starts to deform plastically when the $\sigma_{\text {Mises }}$ reaches the yield criterion yield strength $\left(\sigma_{y}\right)$.

$\sigma_{\text {Mises }}=\sqrt{\frac{\left(\sigma_{1}-\sigma_{2}\right)^{2}+\left(\sigma_{2}-\sigma_{3}\right)^{2}+\left(\sigma_{3}-\sigma_{1}\right)^{2}}{2}}$

Where $\sigma_{1}, \sigma_{2}$, and $\sigma_{3}$ are the three principal stresses. There is no strain hardening behavior of the specimen considered in the model.

The indentation stress and the indentation strain values were obtained directly from the simulation program postprocessor routines where the element under the indenter studied as shown in Fig. (11).

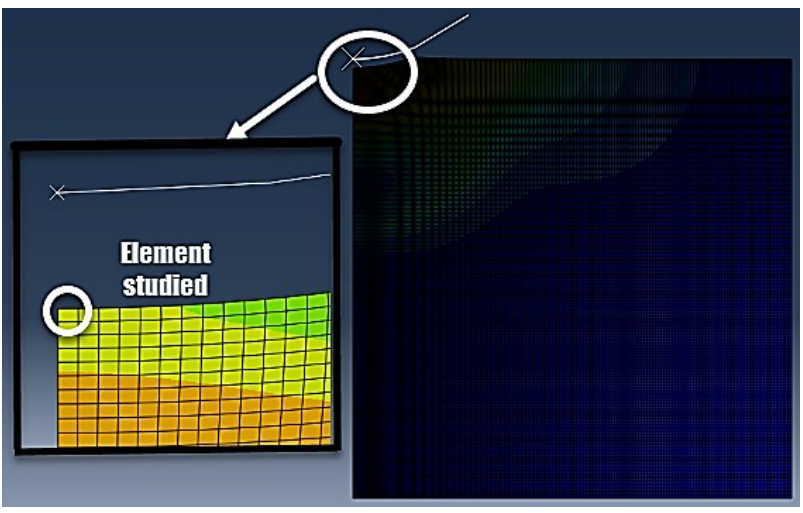

Figure (11). contact element.

It is found that the engineering stress-strain converted directly from the indentation stressstrain curve of a deep spherical indentation test has an agreement with the effective stressstrain value defined by equations (11) and (12). The stress and strain constraint factors have empirical values according to Taber theory and depended on material properties as shown in Table (1) above (Xu \& Chen, 2010).

\section{RESULTS AND DISCUSSION}

Model Validation: To verify the accuracy of the results obtained from FE simulations, as mentioned previously, micro-indentation ex- 
periments were conducted with a Nanovea mechanical tester. The indenters used for the experiment were the spherical indenter $200 \mu \mathrm{m}$ diameter and Vickers indenter with $136^{\circ}$. The Two commercial steel grades that widely used in the engineering applications are the low carbon steels AISI-1010 and ASTM-516-G70.

Fig. (12) Shows comparison between the average experimental curve and simulation loaddisplacement curve of the spherical indenter for AISI1010 and ASTM516G70 materials. As shown, there was an excellent agreement between the experimental and the finite element simulation.

Fig. (13) shows a comparison between the experimental results and the simulation loaddisplacement curves for Vickers indenter. The agreement between results was excellent for both materials (AISI-1010, ASTM-516-G70), which validate the finite element models.

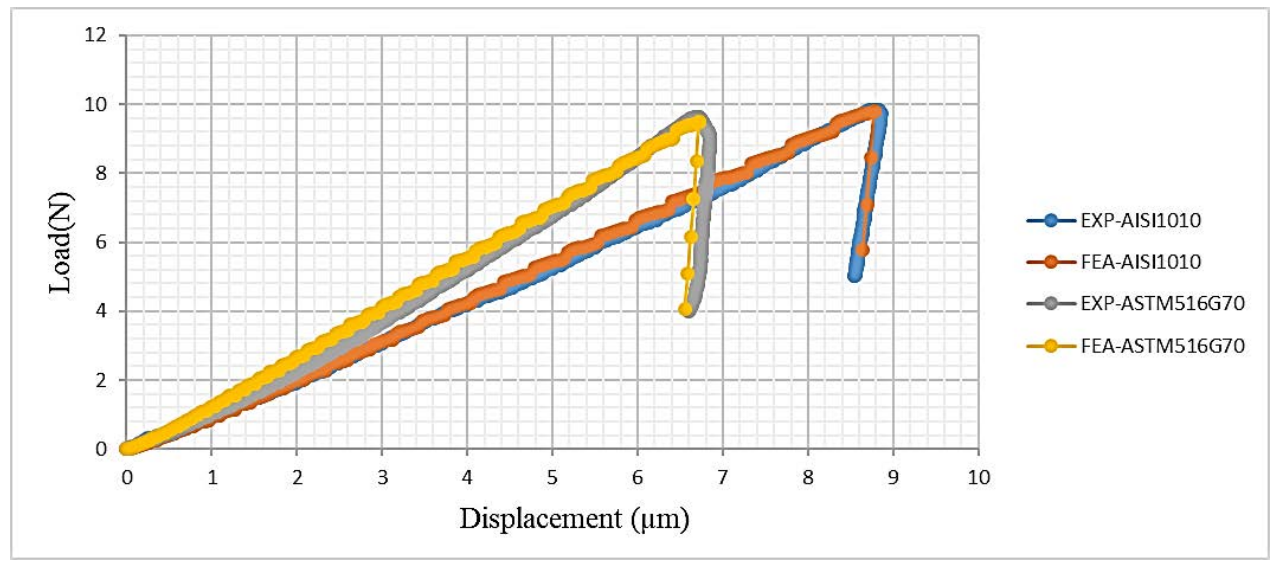

Figure (12). Comparison of F.E simulation and experimental results for spherical indenter.

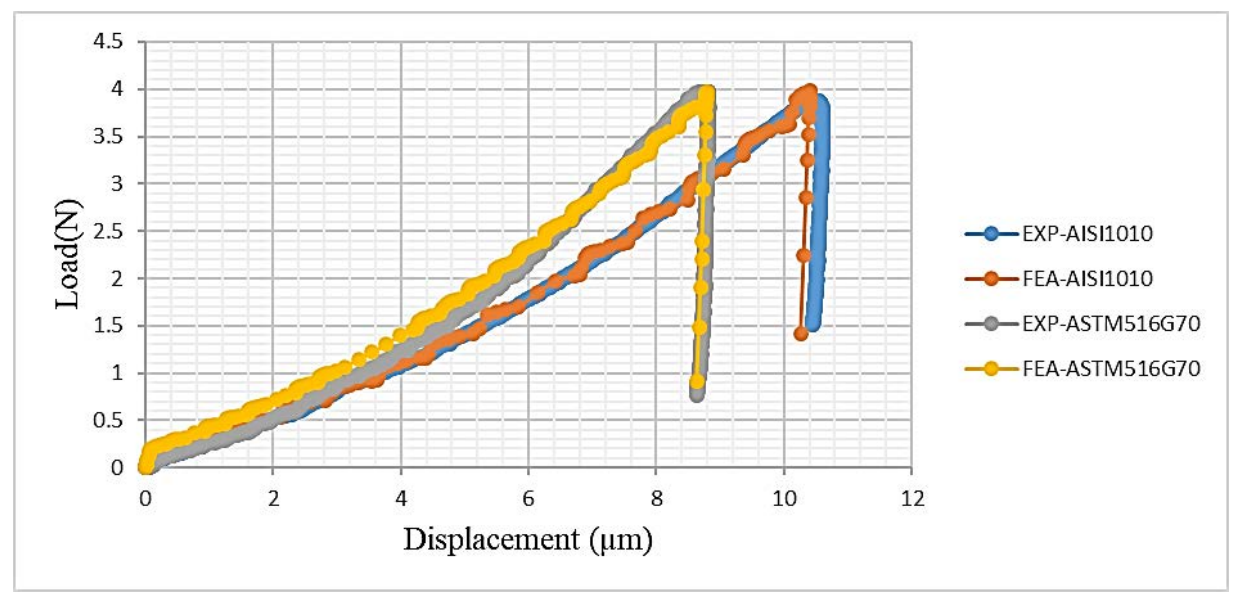

Figure (13). Comparison of F.E simulation and experimental results for Vickers indenter.

This agreement is found to be sufficient to estimate the yield strength and the strain hardening exponent that we obtained from the tensile test and the effective stressstrain curve which is obtained from the indentation test as shown in Table (3). 
Table (3). Comparison of yield strength and Strain hardening exponent from tensile and indentation tests (Spherical indenter).

\begin{tabular}{ccccccc}
\hline \hline \multirow{2}{*}{ Material } & \multicolumn{3}{c}{ Yield strength (Mpa) } & \multicolumn{3}{c}{ Strain hardening exponent } \\
\cline { 2 - 7 } & Tens. test & Inden. test & Err.\% & Tens.test & Inden. test & Err. \% \\
\hline AISI1010 & 220 & 225 & 2.3 & 0.149 & 0.091 & 38.9 \\
ASTM516-G70 & 260 & 280 & 7.7 & 0.154 & 0.139 & 9.7 \\
\hline \hline
\end{tabular}

The relatively high error value of strain hardening exponent is because it was based on a single tensile test, which cannot be considered as a typical or standard curve for the considered materials. This shows that further investigation considering stress-strain curve refining to reduce the error is recommended in the future.

For Vickers indentation, the yield strength and strain hardening exponent values were difficult to find from indentation stress-strain curve method because of the sharp tip of the Vickers indenter which caused the fast transfer from the elastic and elastic-plastic region to the fully plastic region, especially for hard materials or materials that have low ductility.

Modulus of Elasticity Prediction: Table (4) compares results for elastic modulus extracted from experimental and finite element simulation methods and also from the tensile test for spherical indentation test. As shown, a very good agreement was obtained from the finite element simulation model as compared to other methods, and the error $\%$ is within acceptable limits for both materials.

Table (4). Comparison of modulus of elasticity obtained with different methods (spherical indenter).

\begin{tabular}{cccccc}
\hline \hline & \multicolumn{5}{c}{ Modulus of Elasticity (GPa) } \\
\cline { 2 - 6 } Material & Typical & $\begin{array}{c}\text { Tensile } \\
\text { Test } \\
\text { (Exp.) }\end{array}$ & $\begin{array}{c}\text { Inden. } \\
\text { Test } \\
\text { (Exp.) }\end{array}$ & $\begin{array}{c}\text { Inden. } \\
\text { Test } \\
(\text { FEM) }\end{array}$ & $\begin{array}{c}\text { Error } \\
\%\end{array}$ \\
\hline $\begin{array}{c}\text { AISI- } \\
1010\end{array}$ & $190-$ & 203 & 201.6 & $203 . .12$ & 0.06 \\
$\begin{array}{c}\text { ASTM- } \\
516\end{array}$ & 210 & 240 & 253.44 & 252 & 5 \\
\hline \hline
\end{tabular}

The error percentage obtained above is calculated as the $\%$ between the tensile test results and the results of the experimental and the simulation of the indentation test.

For Vickers indentation test, Table (5) compares results for elastic modulus extracted from experimental and finite element simulation methods and also from tensile test.

Table (5). Comparison of modulus of elasticity obtained with different methods (Vickers indenter).

\begin{tabular}{cccccc}
\hline \hline & \multicolumn{5}{c}{ Modulus of Elasticity (GPa) } \\
\cline { 2 - 6 } Material & Typical & $\begin{array}{c}\text { Tensile } \\
\text { Test } \\
\text { (Exp.) }\end{array}$ & $\begin{array}{c}\text { Inden. } \\
\text { Test } \\
(\text { Exp. })\end{array}$ & $\begin{array}{c}\text { Inden. } \\
\text { Test } \\
(\text { FEM) }\end{array}$ & $\begin{array}{c}\text { Error } \\
\%\end{array}$ \\
\hline $\begin{array}{c}\text { AISI- } \\
1010\end{array}$ & $190-$ & 203 & 210.38 & 200.2 & 1.37 \\
$\begin{array}{c}\text { ASTM- } \\
516\end{array}$ & 200 & 240 & 235.92 & 254.25 & 5.9 \\
\hline \hline
\end{tabular}

Extracted Engineering Stress-Strain Curve: Figs.(14 \& 15) shows the FE simulation results for the stress-strain curve with the experimental stress-strain curves overlapped on it for spherical indenter. As shown, there is a good agreement between experimental engineering stressstrain curve and the effective (FE) stress-strain curves. However, a deviation is observed at a later stage of the beginning of the plastic part, as shown. Therefore further analysis is recommended after this stage. The effective stressstrain is obtained by selecting 3.7 for stress constraint factor and 0.11 for strain constraint factor for AISI 1010 and 3.9 and 0.11 for ASTM516-G70. These values are according to published references (Chang et al., 2018; Xu \& Chen, 2010). 


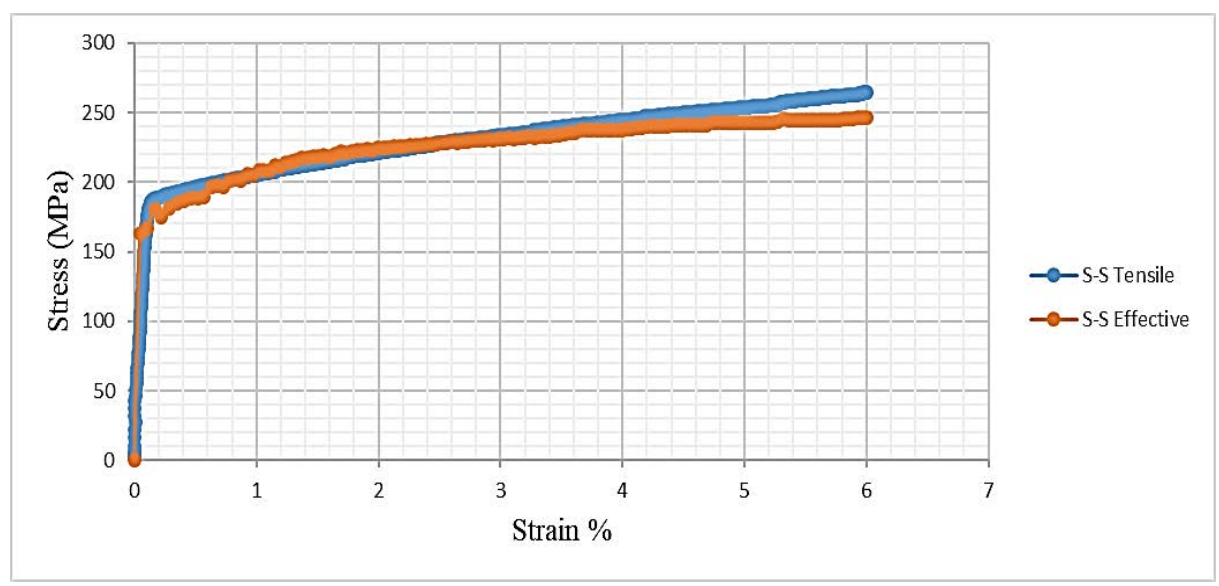

Figure (14). Comparison between F.E simulation and experimental engineering stress-strain curves results for AISI1010.

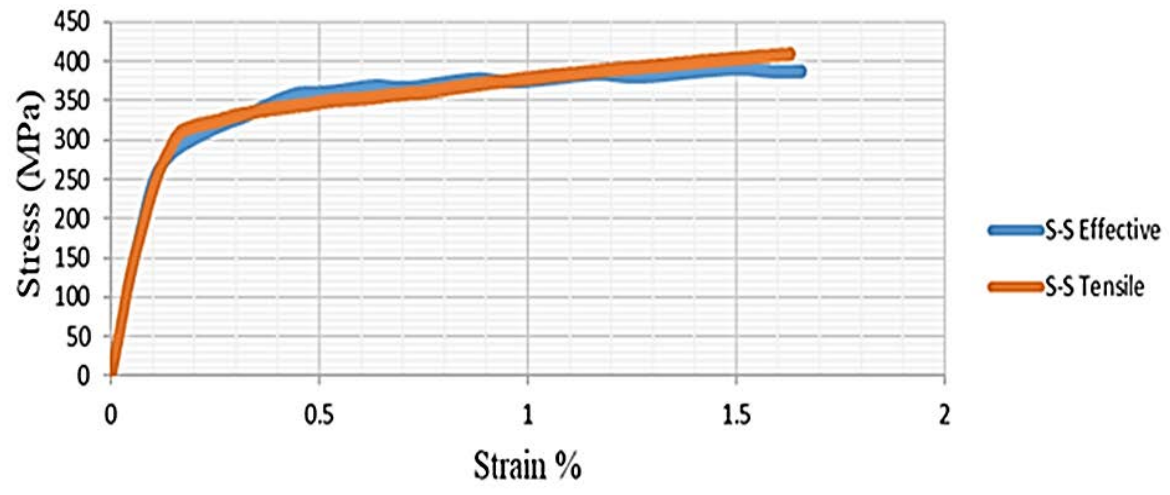

Figure (15). Comparison between F.E simulation and experimental engineering stress -strain curves results for ASTM516-G70

\section{CONCLUSION}

From this study, generally, it is found that finite element simulation has become a powerful tool to study the micro-indentation test and thus to help develop improvements in the analytical theories used to extract mechanical properties from experimental data.

More specifically, in this work, FE simulation of the indentation has been implemented in the ABAQUS software based on the material properties obtained from the uniaxial tensile tests of ASTM516G70 and AISI1010 steel. For these particular materials, the following points have been concluded:The FE simulated loadingunloading curves for both materials agreed well with experimental loading-unloading curves.

- The agreement between the FE simulation and experimental mechanical results is ex- cellent.

- The sensitivity of the response of the model is evaluated in load conditions under the change of strain hardening exponent, fraction coefficient, and boundary condition and were found to be stable.

- As an analytical tool, FE simulation helps to lower the cost and duration of experimental studies by accurate and fast computation.

\section{REFERENCES}

Abaqus. (2014). ABAQUS user's manual. Version 6.14: ABAQUS Providence, RI.

Bhargava, A., \& Sharma, C. (1990). Mechanical Behaviour and Testing of Materials; PHI Learning Pvt. Ltd: New Delhi . 
Bressan, J., Tramontin, A., \& Rosa, C. (2004). Modeling of nanoindentation of bulk and thin film by finite element method. Wear, 258(1-4), 115-122 .

Chang, C., Garrido, M., Ruiz-Hervias, J., Zhang, Z., \& Zhang, L.-1. (2018). Representative stress-strain curve by spherical indentation on elastic-plastic materials. Advances in Materials Science and Engineering, 2018 .

Chen, C. (2009). 2-D finite element modeling for nanoindentation and fracture stress analysis .

Chiang, S., Marshall, D., \& Evans, A. (1982). The response of solids to elastic/plastic indentation. I. Stresses and residual stresses. Journal of Applied Physics, 53(1), 298-311 .

Clayton, J. D. (2005). Spherical Indentation in Elastoplastic Materials: Modeling and Simulation: Army Research Lab Aberdeen Proving Ground Md Weapons And Materials Research.

Doerner ‘M. F., \& Nix, W. D. (1986). A method for interpreting the data from depth-sensing indentation instruments. Journal of Materials research, 1(4), 601-609.

Fischer-Cripps, A. C., \& Nicholson, D. (2002). Nanoindentation. Mechanical engineering series. Appl .Mech. Rev., 57(2), B12-B12 .

Karthik, V., Kasiviswanathan, K., \& Raj, B. (2016). Miniaturized Testing of Engineering Materials: CRC Press.

Kimmari, E., \& Kommel, L. (2006). properties of B4C/A1 composites. Paper presented at the Proceedings of the Estonian Academy of Sciences, Engineering.

Knapp, J., Follstaedt, D., Barbour, J., \& Myers, S. (1996). Finite-element modeling of nanoindentation for determining the mechanical properties of implanted layers and thin films. Nuclear Instruments and Methods in Physics Research Section B: Beam Interactions with Materials and Atoms, 127, 935939 .

Midawi, A. R., Kisaka, Y., Santos, E., \& Gerlich, A. (2016). Characterization of Local Mechanical Properties of X80 Pipeline Girth Welds Using Advanced Techniques. Paper presented at the 2016 11th International Pipeline Conference.

Oliver, W. C., \& Pharr, G. M. (1992). An improved technique for determining hardness and elastic modulus using load and displacement sensing indentation experiments. Journal of materials research, 7(6), 1564-1583 .

Panich, N., Kraivichien, V., \& Yong, S. (2004). Finite element simulation of nanoindentation of bulk materials. Journal of Scientific Research of Chulalongkorn University, 29(2), 145153 .

Rabinowicz, E., \& Tabor, D. (1951). Metallic transfer between sliding metals: an autoradiographic study. Proceedings of the Royal Society of London. Series A. Mathematical and Physical Sciences, 208(1095), 455-475 .

Xu, B., \& Chen, X. (2010). Determining engineering stress-strain curve directly from the load-depth curve of spherical indentation test. Journal of Materials Research, 25(12), 2297-2307 .

Yang, F., \& Li, J. C.-M. (2008). Micro and nano mechanical testing of materials and devices: Springer. 


\title{
المحاكاة الرقمية لاختبار الصلادة الحديث كأداة لحساب الخصائص الميكانيكية للمواد (AI6 516 -ASTM 70) و (AISI1010 ) الفولاذية
}

\author{
أحمد فوزي المستيري، عبد الباسط رمضان إمضاوي، فرج محمد شعيب"

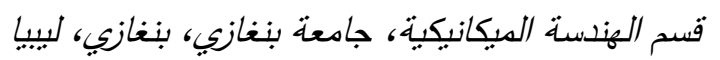

تاريخ الاستلام: 14 مارس 2019 / تاريخ القبول: 15 نوفمبر 2019 :/doi.org/10.54172/mjsc.v34i3.273
بhttps:/doi

المستخلص: أصبحت طريقة اختبـار الصـلادة الحديث من الاختبارات المشهورة في عالم قياس الخصـائص الميكانيكيـة للمواد كالصلادة ومعامل المرونة وإجهاد الخضوع كما أصبحت كطريقة لإيجاد منحنى الإجهاد والانفعال الناتج من اختبار الثد التقليدي

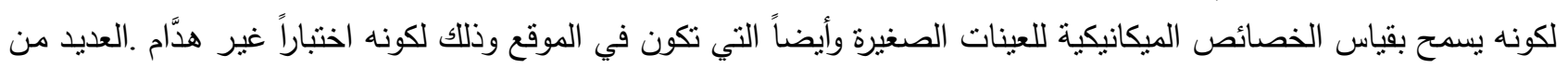

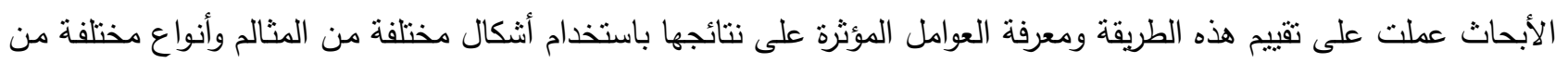
المواد. لتقييم هذه الطريقة اختير نوعين من حديد الفولاذ هما (ASTM 516 G 70 , AISI 1010) و باستخدام شكلين مختلفين من المثالم هما الكروي و المسنن (Spherical , Vickers) حيث أجري تحليل المحاكاة الرقمية باستخدام طريقة العناصر المتتاهية (FEM) بواسطة برنامج الأباكوس (ABAQUS) و مقارنة النتائج المتحصل عليها مـع نتائج الاختبار العملي والتي أجريت لهذه المواد تحت نفس الظروف في هذا البحث ؛ النتائج التي تحصلنا عليها نظهر نوافقا بين (Experimental) النتائج المتحصل عليها من الاختبار العملي و النتائج المتحصل عليها من المحاكاة الرقمية حيث إن نسبة الاختلاف في معامل المرونة كانت لا تتجاوز 5\% و 7.7\% لإجهاد الخضوع .بالإضافة للخصائص الميكانيكية تم إيجاد منحنى الإجهاد و الانفعال

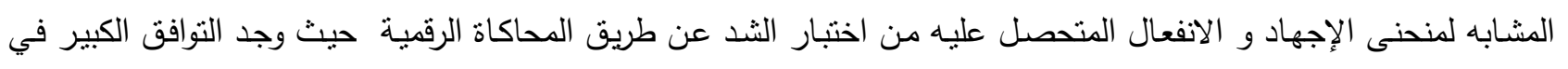

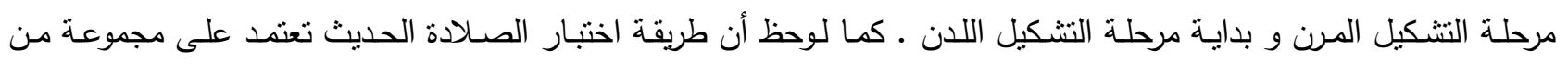

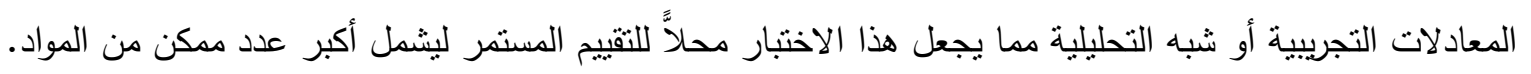
الكلمات المفتاحية: اختبار الصلادة، طريقة العناصر المتتاهية، المحاكاة الرقمية، الخصائص الميكانيكية.

"فرج محمد شعيب dedfmshuaeib@gmail.com قسم الهندسة الميكانيكية ، جامعة بنغازي ، بنغازي ، ليبيا. 